\title{
Polish Take on Realism: Poland's Policy Towards the Former Soviet Countries, 1991-2021
}

\author{
Andrzej Szeptycki, University of Warsaw, Warsaw, Poland
}

Correspondence: andrzej.szeptycki@uw.edu.pl

\begin{abstract}
This article analyzes Poland's policy towards the former Soviet space (Poland's Eastern policy) through the assumptions of the realist theory of international relations. The first part of the article examines the realist theory in international relations (IR). The second - deals with the existing literature on Poland's foreign policy. The third part analyses the determinants and the goals of Poland's policy towards the post-Soviet states (history of its relations with the region, ideological determinants, security concerns, etc.). The last part inquires about the evolution of Poland's policy till current times. The Russian Federation is perceived as a significant threat by Poland. In that

context, since the early 1990s, Poland has been seeking solutions to strengthen its security. It aimed to join the North Atlantic Alliance and establish a close partnership with the United States (bandwagoning). This strategy brought substantial effects - in 1999, Poland joined NATO, and since it has hosted allied troops. Poland also wanted to develop cooperation with Ukraine (to a lesser

degree also with its other post-Soviet neighbors) and bring them closer to the Euro-Atlantic structures. This policy was, in particular, at weakening Russia's influence in the region (balancing).

The results of this strategy have been somewhat ambiguous, though. Ukraine has rejected Russia's sponsored reintegration projects in the post-Soviet space. The process of reforms in that country, however, is slow and uncertain. As for other post-Soviet states, Poland has largely proven unable to influence the desired changes.
\end{abstract}

\section{KEYWORDS}

Poland, foreign policy, Russia, Eastern Europe, realism 
Until 1991, the USSR was Poland's biggest immediate neighbour, as well as the dominant power on which Poland had been dependent since the second half of 1940s. ${ }^{1}$ It is therefore fully understandable that the post-Soviet space continued to be a key are of Poland's foreign policy after the collapse of the bipolar system. This interest in the post-Soviet states however has been rather "uneven."

At the beginning of the 1990s Poland's policy focused on Ukraine, Lithuania and Belarus (known as the "ULB" states), as well as Russia. Currently, the Baltic republics are close partners of Poland, but being members of EU and NATO like Poland, they are not perceived any more as part of the former Soviet space. Poland's policy towards the post-Soviet space focuses currently on the states of Eastern Europe (Ukraine, Belarus and Moldova), the South Caucasus (Georgia, Armenia and Azerbaijan), and the Russian Federation. The Central Asian republics play a much lesser role in the Polish political agenda.

The aim of this article is to analyse Poland's policy towards the former Soviet countries from 1991 to 2021 through the lenses of the realist theory of international relations. Poland's policy towards its Eastern neighbours has been extensively studied by both Polish, Russian and Ukrainian scholars, but most often without an appropriate theoretical framework. This article aims at filling this gap. The realism assumes that states define their interests in terms of power, and they compete for power, as well as for assets, which form its material basis. The realist paradigm is of importance for the analysis of the Polish policy towards the post-Soviet space. Indeed, since the 1990s, Poland has seen the Russian Federation as a challenge - and later a threat - because of its assertive policy. Despite their largely unequal potential, the two countries compete in the common neighbourhood, in particular in Ukraine. ${ }^{2}$

The structure of the article is the following. In the first part the realist theory of IR is presented. The second part focuses on the existing literature of the topic. The third part discusses the determinants and the aims of the Polish policy towards the postSoviet region. The last one analyses its evolution from 1991 to 2021.

\section{Poland's Foreign Policy and Realism: Back to the Basics}

Realism is commonly associated with T. Hobbes' concept of "the war of all against all," which assumes that states define their interests in terms of power. Power is an objective category, which is universally valid, but its meaning may change over the time. In other words, power is the control of human over human. Realism attaches a lesser role to morals and principles, even if it does not deny either their existence or influence on foreign policy. ${ }^{3}$

In the light of classical realism, the conflict that is inherent to international relations can be explained by human nature At the same time, the neorealists believe that the international system's anarchical structure stands as a primary source of uncertainty and power struggle. ${ }^{4}$ Defensive realists claim that, under certain conditions (a solid

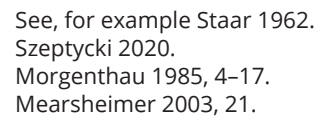


national identity or technological development, for example), the war-causing potential of anarchy can be attenuated. Meanwhile, offensive realists argue that even today states cannot be confident in their security and must always view an increase of another state's power as a threat. This is why they are tempted to expand or otherwise strengthen themselves. ${ }^{1}$

According to $\mathrm{H}$. Morgenthau states compete for power, as well as for assets, which form the material basis of their military power, such as population or wealth. ${ }^{2}$ They compete in particular for domination over third countries: "the pattern of the struggle for power (...) is here not one of direct opposition, but of competition."3 States may adopt either a policy of status quo, or a policy of imperialism; a third possibility is the policy of prestige, which is rarely an end in itself, but more often an instrument of the policy of status quo or imperialism. ${ }^{4}$

In that context, smaller states can choose one of the two basic security strategies: balancing or bandwagoning. According to K. Waltz, balancing strategy assumes that states will in particular form alliances with other powers to balance against great powers, while the bandwagoning refered to the policy of states, which ally with the great powers seeking their security assurance. ${ }^{5} \mathrm{~S}$. Walt proposed a slightly different understanding of the two concepts. He believed that states perceive the external environment not through the prism of distribution of power, but through the level of threat, depending on the geographic proximity, offensive capabilities and perceived intentions. They respond to threats in two ways - by balancing (allying against the threat) or bandwagoning (allying with the threat). Among the less powerful states the balancing behaviour is much more popular; many ideological alliances were in fact a form of balancing. ${ }^{6}$ R.L. Schweller disagreed with the supposed opposition between balancing and bandwagoning. The aim of balancing was self-preservation and the protection of the assets already possessed (balancing always entails some costs related to their protection), while the bandwagoning was motivated by the opportunity for gain. The presence of significant external threat was necessary for effective balancing; in case of bandwagoning it was not required. ${ }^{7}$

\section{IR Scholarship on Poland's Foreign Policy}

Since the 1990s, Poland's Eastern policy (a term that is broadly more popular than "policy towards the post-Soviet space") has been extensively studied both in Poland and, to a lesser extent, in some post-Soviet and Western countries. ${ }^{8}$ This is particularly true of Poland's relations with Russia and Ukraine

Poland's policy towards the Russian Federation and the bilateral relations between the two countries have been studied in detail by J. Gorska, ${ }^{9}$ M. Stolarczyk, ${ }^{10}$

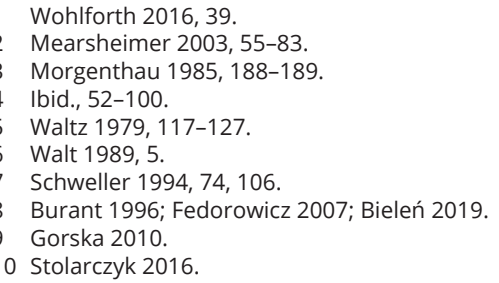


R. Lisiakiewicz, ${ }^{1}$ N. Bukharin, ${ }^{2}$ I. Yazhborovskaya, ${ }^{3}$ A. Rotfeld and A. Torkunov. ${ }^{4}$ A number of Polish and foreign authors have also analysed Poland-Russia relations in their historical context, ${ }^{5}$ focusing in particular on the most controversial episodes in their shared past, such as the Katyn massacre. ${ }^{6}$ Scholars have scrutinized the evolution of bilateral relations over the past 30 years, in particular such key events as the crash of Polish presidential plane in Smolensk in 2010.7 Several works have been published on the security aspects of Poland-Russia relations, ${ }^{8}$ as well as the politics of memory in the two countries. ${ }^{9}$ In terms of economics, the energy sector has dominated the expert discussion, most notably Poland's position on the Nord Stream 2 pipeline project. ${ }^{10}$ There have also been a number of publications on Poland and the Kaliningrad Region, ${ }^{11}$ specifically on Poland's policy towards the Russian exclave.

Poland's policy towards Ukraine has been analysed in depth by K. Fedorowicz, ${ }^{12}$ P. Kuspys, ${ }^{13}$ O. Boryniak, W. Walak, I. Hurak, ${ }^{14} \mathrm{~K}$. and R. Wolczuk, ${ }^{15}$ as well as A. Szeptycki. ${ }^{16}$ Sectorial analyses have covered the evolution of political relations between the two countries, ${ }^{17}$ the role of energy issues ${ }^{18}$ and Ukrainian migration to Poland, ${ }^{19}$ as well as the different interpretations of historical events between the two countries, particularly those of the $1940 \mathrm{~s}^{20}$ Several studies have been devoted to the Polish contribution to the political and economic transformation of Ukraine and to Poland lobbying of the latter's interests in the European Union. ${ }^{21}$

The publications on Poland's bilateral relations with other post-Soviet countries are less numerous. The regional approach predominates, ${ }^{22}$ with studies of Poland's policy towards the ULB region ${ }^{23}$ and the Eastern Partnership countries being particularly abundant. ${ }^{24}$ The Yearbook of Polish Foreign Policy published by the Polish Institute of International Affairs is a notable exception, as it includes almost article on Poland's policy towards Belarus, ${ }^{25}$ and, less frequently, on its relations with the South Caucasus and Central Asia. ${ }^{26}$

Most of the above-mentioned publications (at least those relative to IR studies) is that they lack a theoretical framework. Notable exceptions here are the works of such

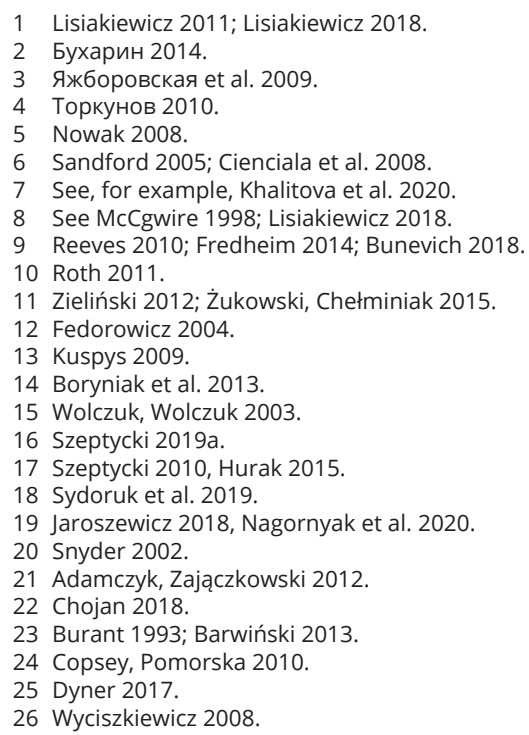


authors as A. Nowak, ${ }^{1}$ who applied the imperial studies concepts to Poland's relations with its Eastern neighbours (in particular Russia), S. Bieleń and A. Skrzypek, ${ }^{2}$ who analyzed the Poland-Russia relations through the prism of geopolitics, S. Bukharin and N. Rakitiansky who proposed to study them through the concept of "limitrophisation", V. Feklyunina, ${ }^{3}$ who opted for social constructivist approach or A. Dudek who claimed that a theoretical eclecticism was the best solution to understand the relations between the Russian Federation and Poland. ${ }^{4}$ Though not that many articles took on some sort of theoretical digestion of Poland's foreign policy, there are no realist studies on Poland's policy, which sometimes aborts the country of its agency in international lieu. This article aims at partially filling this gap by analysing Poland's Eastern policy through the lenses of the realist theory of international relations.

\section{Eastern Policy: Determinants and Aims}

Poland's Eastern policy is largely shaped by the history of its relations with the regional nations. Poland (or, to be more precise, the Polish-Lithuanian Commonwealth) was a major player in the region in the XVI-XVII centuries. Later Poland became dependant on Imperial Russia and the USSR. This complex past explains the interest of Poland in its Eastern neighbours, as well as the importance and the multitude of its policies. Speaking in terms of cultural underpinning of its policy, Poland's goals in that area can be summarized in three points. First, Polish foreign policy aims to protect the heritage of its presence in the East: this concerns in particular old Polish cemeteries, catholic churches and other Polish architectural monuments, as well as Polish ethnic minorities in the post-Soviet states. Second, Poland seeks to advance the "historical truth," that is, an interpretation of the common Eastern European past that would conform to the Polish historiography. ${ }^{5}$ Third, Poland hopes to overcome the conflicts of historical memory, in particular through seeking historical events and figures that could serve as common symbols for both Poland and some of its Eastern partners. It should be noted that the last two aims are at least partially contradictory.

The ideological foundations of Poland's Eastern policy are defined by the political thought of J. Piłsudski, R. Dmowski, J. Giedroyc and the "Solidarity" trade union. J. Piłsudski, the main founder of independent Poland in 1918, saw Russia (later the Soviet Union) as the biggest threat. For this reason, he favoured cooperation with Germany and Austria-Hungary, and the creation of a federation of the nations that had once formed the Polish-Lithuanian Commonwealth. R. Dmowski, J. Piłsudski's coeval and political rival, thought the biggest threat came from Germany, and thus favoured cooperation with Russia. He also wanted to create a unitary nation-state. ${ }^{6}$ These two opposites approaches continue to shape Poland's Eastern policy today. J. Giedroyc and his collaborators from Kultura, a monthly journal published by a group of Polish émigrés intellectuels in France and then smuggled to communist Poland, were the first

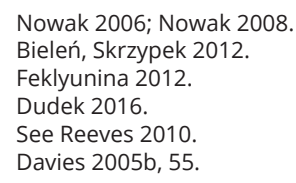


among the Polish elites to recognize both the right of ULB for independence and their post-war borders, even if they included cities of major importance for Poland, such as Lviv and Vilnius. J. Giedroyc's political thought was popular among the Polish political elites following the fall of communism, and was instrumental in the establishment of peaceful relations with Poland's Eastern neighbours.

One of the major factors that shapes Poland's policy in the region today is security challenges. Since the early 1990s, the post-Soviet space has been seen as highly volatile due to the number of domestic and regional conflicts, the high level of crime and corruption, etc. Poland has been particularly worried by Russia's policies, both within the post-Soviet space and outside it. This position has been motivated by Polish historical memory as well as a drastic asymmetry of power potential between the two states in favor of Russia (for a detailed elaboration see Table). Security challenges also include Poland's energy dependence on Russia. Eighty-nine percent of Poland's foreign gas imports in 2016, and 60\% in 2019, came from Russia. ${ }^{1}$ This makes the nation to seek to balance such an asymmetry: leveraging highly asymmetric networks by a greater state $\mathrm{H}$. Farell and A. Newman called "weaponized interdependence." 2 The challenges emanating from the post-Soviet space are therefore of major importance for Poland's security policy. However, the responses to these challenges have been primarily formulated without regional partners, as Poland's security policy has been based essentially on its membership in NATO (and to a lesser degree the EU) and close bilateral cooperation with the United States. ${ }^{3}$ Nevertheless, Poland is pursuing some projects with post-Soviet partners, such as the Polish-Ukrainian Peace Force Battalion, which would later become the Lithuanian-Polish-Ukrainian Brigade, or the OdessaBrody pipeline project, which was to be a part of the Eurasian petroleum transport corridor connecting Caspian producers and EU consumers, which never got off the ground. ${ }^{4}$

Table.

\section{POLAND AND RUSSIA: MAJOR POWER INDICATORS РОССИЯ И ПОЛЬША: КЛЮЧЕВЫЕ ПОКАЗАТЕЛИ МОЩИ}

\begin{tabular}{lcc}
\hline & Poland & Russia \\
\hline Surface area (thousand square kilometres) & 312,7 & 17,0982 \\
\hline Gross domestic product (2019, in billion dollars) & 596 & 1699 \\
\hline Military expenditure (2019, current billion dollars) & 11,9 & 65,1 \\
\hline Composite Index of National Capability (2012) & 0,005493 & 0,0400789 \\
\hline
\end{tabular}

Source: Correlates of War Project, "National Material Capabilities (v5.0)," accessed April 1, 2021, http://correlatesofwar. org/data-sets/national-material-capabilities/nmc-v5-1/at_download/file.

Note: The Composite Index of National Capacities is based on six indicators - military expenditure, military personnel, energy consumption, iron and steel production, urban population, and total population. For more see Singer 1987.

1 Vitaly Yermakov, "Poland Counts the Cost of Turning Down Russian Gas Taps," Financial Times, June 17, 2020, accessed February 2, 2021, https://www.ft.com/content/78d764c1-b60d-478d-9c7e-a4a9d860edcb.

2 Farell, Newman 2019.

3 Kuźniar, Szeptycki 2005; Balcerowicz 2011.

4 Szeptycki 2019a, 105-106, 149-152. 
Poland's accession to the North Atlantic Treaty Organization in 1999 and the European Union in 2004 have for many years been seen not only as important tool of Poland's security policy, but also as the most reliable path towards modernization and the confirmation of the successful transformation of Poland launched in 1989 and its belonging to the West. It was thought that membership in both organisations would also strengthen Poland's position in international relations and to serve as a tool of its foreign policy, in particular with regard to the post-Soviet space. Poland aims to bring its Eastern neighbours (or at least some of them, such as Ukraine, Moldova and Georgia) closer to West, both through the implementation of Western (EU) standards in these countries and through the development of cooperation between these states and the Western structures. In Poland's opinion, such an approach meets the needs of both these former Soviet countries and Poland. If Ukraine, Moldova and Georgia were to accept Western (EU) standards, this would mean improved democracy and the supremacy of the rule of law in these countries. Moreover, it would facilitate economic reforms and improve the standard of living. NATO accession would be the best of the available ways to guarantee security. At the same time, the expansion of Euro-Atlantic structures eastward would relieve Poland of its status as a border state at the point of contact between the EU/NATO and the post-Soviet space. Increased internal stability in the Eastern European and South Caucasus republics would also reduce migration pressure and the threat that a political crisis in the region could bring, potentially turning one of its neighbours into a fallen state. ${ }^{1}$

Concluding, since 1990s two key dimensions of Polish Eastern policy were, first, to develop Poland's and Western institutions' relations with the post-Soviet states (in particular Ukraine, in a lesser way other EaP countries) and second to prevent the rise of influence of the Russian Federation in Central and Eastern Europe. ${ }^{2}$

\section{Evolution of Poland's Policy}

Poland's Eastern policy from 1991 to 2021 can be divided into five main stages, which correspond partially to internal political changes in Poland. After the fall of communism in Poland (1989), the new foreign policy was largely shaped by the former "Solidarity" advisors and the first non-communist minister of foreign affairs, K. Skubiszewski, who focused in particular on obtaining confirmation of Poland's borders and regaining full sovereignty. In 1990, Poland launched a so-called dualtrack policy aimed at maintaining diplomatic relations with the Soviet Union and developing contacts with Soviet republics bordering Poland. In the summer of 1991, Poland was instrumental in the eventual disbandment of key Soviet bloc institutions - the Warsaw Pact and the CMEC. In December 1991, Poland was the first country in the world to recognise the independence of Ukraine, which laid the ground for the development of good relations between the two countries. In 1992, it signed interstate treaties with Russia, Ukraine and Belarus. Poland also negotiated the withdrawal of Soviet troops from the country, with a preliminary agreement being reached in 1991 and the last remaining soldiers being pulled out 
in 1993. The basic aims of Poland's foreign policy during that period had thus been achieved. ${ }^{1}$

From 1993 up to the eve of the new millennium, Polish foreign policy focused on accession to the North Atlantic Alliance and the European Union. It perceived the membership in NATO and the alliance with the US as the best guarantee of its security, in particular against Russia. It hoped also that close cooperation with the United States might brough it some additional profits (which is basically out of scope of this article), such as elimination of the American visa regime for Polish passport holders, easier purchase of the US military equipment, access to the oil fields in the Middle East etc. ${ }^{2}$ Such an attitude can be qualified as a typical bandwagoning strategy. Polish désintéressement for the Eastern neighbours was also due partly to the situation in the region. From 1993, the relations between Russian Federation and the West became more conflictual, in particular because of the planned NATO Eastern enlargement, Russia was very critical about. ${ }^{3}$ The attempts to improve bilateral relations launched by the post-communist Democratic Left Alliance that came to power in 1993 proved to be unsuccessful. ${ }^{4}$ In Belarus, Lukashenko opted for rapprochement with Russia, which limited the possibilities of cooperation. In fact, the only potentially interesting partner left was Ukraine. And, starting in 1996, President of Poland A. Kwaśniewski and President of Ukraine L. Kuchma worked tirelessly to bring their countries together and develop bilateral relations.

As the membership in NATO (1999) and EU (2004) became a fact, Poland adopted a more active Eastern policy aiming at bringing its neighbours (in particular Ukraine) closer to the Western structures, ${ }^{5}$ in particular to counterbalance the Russian influence in the region. It played a major role in the resolution of the political crisis during the Orange Revolution (2004), which led to the election of the pro-Western V. Yushchenko as president. Poland's cooperation with Ukraine went from strength to strength, with the countries winning their joint bid to host the 2012 UEFA European Football Championship in 2007. At the same time, relations with Russia deteriorated considerably. ${ }^{6}$ The Russian authorities saw the Orange Revolution as a plot against the Russian interests in the region. Within a few years, the post-2004 enthusiasm of Polish foreign policymakers had progressively faded away. The Yushchenko team proved to be largely unable to introduce the necessary reforms in Ukraine. Historical problems continued to poison relations between Poland and Ukraine. Poland's lobbying for Ukraine to become a member of the North Atlantic Alliance and the European Union was unsuccessful, one of the reasons being the opposition of Russia, which was very critical about granting Ukraine the NATO Membership Action Plan (NATO Bucarest summit, 2008).

All these factors made Poland adopt a more realistic approach towards the Eastern neighbourhood. When Donald Tusk's Civic Platform came to power in 2007, its immediate goal was to reset relations with the Russian Federation. And he achieved a

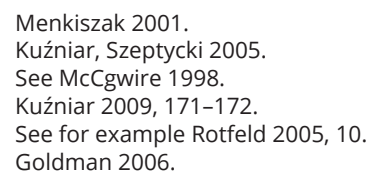


modicum of success in this regard. In 2009, then Prime Minister V. Putin was the guest of honour at an event to commemorate the $70^{\text {th }}$ anniversary of the start of the Second World War in Poland. In 2010, the Polish presidential plane crashed near Smolensk Airport, as representatives of Polish elites were heading to Katyn to pay homage to the Polish officers who were killed there in 1940. All the passengers and crew members, including President L. Kaczyński and his wife, died. It initially appeared as though the tragedy might contribute to a rapprochement between the two countries, but it soon became a divisive issue, primarily because the sides blamed each other for the crash. ${ }^{1}$ At the same time, Poland redefined its policy towards other post-Soviet states, opting for more limited, but tangible aims. In 2008, Poland and Sweden proposed a new instrument of cooperation with the post-Soviet neighbours to EU. The Eastern Partnership was launched the very next year by the European Union and its six neighbours - Ukraine, Belarus, Moldova, Georgia, Armenia and Azerbaijan. The EU offered these states association agreements, the creation of Deep, Comprehensive Free Trade Areas (DCFTA), the prospect of a visa-free regime, and cooperation on energy. ${ }^{2}$ Within few years, the EU-Ukraine Association Agreement had become an issue of major importance. From 2011 to 2013, the European Union was reticent to sign the agreement because democratic standards had deteriorated under President V. Yanukovych. Poland lobbied for the agreement to be adopted, fearing that the isolation of Ukraine may strengthen Russian influence there. The EU had a change a heart in 2013, but this time it was Ukraine that decided not to sign the agreement, and this is what led to the Euromaidan. Poland, together with Germany and France, unsuccessfully mediated between the Ukrainian authorities and opposition. The Polish side considered the fall of Yanukovych and the change of power in Ukraine as a success of democratic and pro-Western forces. The international consequences of the Euromaidan (the incorporation of Crimea and the war in Donbas) were seen by Poland as major challenge for both Polish and European security. For that reason, Poland consistently opted for EU sanctions against the Russian Federation.

In 2015, major political changes took place in Poland, as the Law and Justice party won both the presidential and parliamentary elections. The new authorities adopted a unanimously pro-American foreign policy, perceiving the US as the best guarantee of Poland's security against Russia. At the same time, they were less interested in cooperation with the post-Soviet countries. Poland came back to the bandwagoning strategy at the expense of the cooperation with its Eastern neighbours.

The Polish government has remained critical of Russia, especially in the context of the conflict in Donbas. This policy has brought some tangible results within Western structures. The EU has continued its policy of targeted sanctions against Russia. In accordance with the decision made at the 2016 Warsaw Summit of the North Atlantic Treaty Organization, NATO troops have been present in Poland since 2017. And construction of Nord Stream 2 appears to have stopped completely, even though most of the pipeline has already been finished. However, some key bilateral problems remain unsolved. Despite efforts from the Polish side, part of the Soviet archives related to 
the Katyn massacre remains classified and therefore inaccessible to Polish and Western scholars, while the wreckage of the presidential plane is still in Russia. What is more, relations between Poland and the rest of the European Union have faltered as of late, which has weakened the country's influence on the European Union's Eastern Partnership policy and damaged the EU's unity against Russia. That notwithstanding, Poland has not followed in the footsteps of Hungary, which is trying to balance its poor relations with the EU through cooperation with Russia. Relations with Ukraine have also cooled, in particular because of the nationalist historical policies of the post-revolutionary authorities in Ukraine and the Law and Justice party in Poland. In 2015, the Ukrainian parliament recognized the Ukrainian Insurgent Army (UPA) as fighters for the country's independence, which angered the Polish authorities. In 2018, Poland changed the law on the Polish Institute of National Remembrance, equating the Ukrainian underground during the Second World War to the Nazis, which deepened the crisis in bilateral relations. These changes were later recognized as contrary to the constitution, and thus not valid, by the Polish Constitutional Tribunal. The two countries have embarked on a relatively successful reset in their relations following the election of V. Zelensky as President of Ukraine in 2019. In 2020, the presidents of the two countries reaffirmed their commitment to the Poland-Ukraine "strategic partnership."

Relations with Belarus remain basically unchanged. For a time, the Polish authorities sought a rapprochement with Belarus (in 2017-2018), probably to prove the effectiveness of their Eastern policy, but with no tangible results. Poland supported the protests in Belarus against the falsified presidential elections in August 2020, and that September, Svetlana Tikhanouskaya was officially received by Prime Minister of Poland Mateusz Morawiecki. ${ }^{1}$ However, it is Lithuania, not Poland, that has become one of the main proponents of the democratic transformation of Belarus in the region. ${ }^{2}$

\section{Conclusions}

The analysis of Poland's policy towards the post-Soviet states (mainly Russia, Ukraine, and Belarus) brings some insight into the realist theory of international relations. First, Poland perceives Russia as a threat. Such a situation is due to a strong asymmetry of capabilities between the two countries disfavouring Poland and other factors described by S. Walt. In Poland's opinion, the attempts to establish stable partner relations with the Russian Federation (after 1993, 2007-2010) have failed, forcing it constantly to seek solutions to strengthen itself against Russia. In that context, for the last 30 years, Poland has adopted two types of strategies. First, it aimed at joining NATO and establishing close ties with the US. Such policy was motivated both by the need to face the Russian threat and the hope of realizing additional gains through cooperation with the United States (this last topic being basically out of the scope of this article). This strategy was predominant in Poland's foreign policy in the 1990s and again since 2015. It has brought tangible results - in 1999, Poland became a member of the North Atlantic Alliance, and since 2017 it has hosted NATO military forces.

1 "Polish PM, Tsikhanouskaya Discuss Help for Belarusian Opposition," Polish Radio, October 21, 2020, accessed February 4, 2021, https://www.polskieradio.pl/395/7785/Artykul/2605415,Polish-PM-Tsikhanouskaya-discuss-help-for-Belarusian-opposition.

2 Kinga Raś, "The End of Lithuania's Cautious Friendship with Belarus," Bulletin 1635, no. 205, Polish Institute of International Affairs, October 8, 2020, accessed February 4, 2021, https://pism.pl/file/4c074df7-0ca4-449e-9318-dae0d630aa20. 
Second, Poland has been striving to strengthen cooperation with its other postSoviet neighbors (in particular Ukraine) and bring them closer to NATO and the EU. Such policy aimed, in particular, at weakening (counterbalancing) the Russian influence in the region; that is why it might be qualified as a peculiar type of balancing strategy.

In that aspect, Poland's policy led to competition with Russia over Ukraine, which was visible during the Orange Revolution, at the NATO Bucharest summit, or during the talks on the EU-Ukraine association agreement.

Also, the balancing strategy brought mixed results. Ukraine has not followed the Belarussian model, rejecting the authoritarian political system and pro-Russian policy, even though it has remained a highly corrupt and unstable country. As for Belarus and other post-Soviet states, Poland has largely proven unable to influence the desired changes. Such a situation is due to several factors: the relative lack of interest of Western countries in former Soviet states, Poland's limited political and economic potential, and Russia's unwavering interest in its "close neighborhood."

\section{СПИСОК ЛИТЕРАТУРЫ / REFERENCES}

Белые пятна, черные пятна: сложные вопросы в российско-польских отношениях. Научное издание / Под общ. ред. А.В. Торкунова, А.Д. Ротфельда., М.М. Наринского. - М.: Аспект Пресс, 2010. - 823 c. [Torkunov, Anatoliy V., Adam D. Rotfel'd, eds. White Spots, Black Spots: Complex Issues in RussianPolish Relations [Belye piatna, chernye piatna: slozhnye voprosy v rossijsko-pol'skih otnosheniiah]. Moscow: Aspekt Press, 2010] [In Russian].

Бухарин, Н.И. Россия-Польша: опыт двадцатилетних отношений: 90е годы XX века - первое десятилетие XXI века. - СПб.: Нестор-История, 2014. 204 c. [Bukharin, Nikolai I. Russia-Poland: Twenty-Year Experience: 1990s - First Decade of the Twenty-First Century [Rossija - Pol'sha: Opyt dvadtsatiletnihh otnoshenii: 90-e gody XX veka - pervoe desiatiletie XXI veka]. Moscow: Nestor-Istoriia, 2014] [In Russian].

Яжборовская И.С., Яблоков А.Ю., Парсаданова B.C. Катынский синдром в советско-польских и российско-польских отношениях. 2-е изд. - М.: РОССПЭН, 2009. -519 с. [Yazhborovskaya, Inessa, Anatoliy Jablokov, and Valentina Parsadanova. The Katyn Syndrome in Soviet-Polish and Russian-Polish Relations [Katynskiy sindrom v sovetsko-pol'skikh i rossiyskopol'skikh otnosheniiah]. Moscow: ROSSPYEN, 2009] [In Russian].

Adamczyk, Artur, and Kamil Zajączkowski, eds. Poland in the European Union: Adjustment and Modernisation. Lessons for Ukraine. Warsaw: Centre for Europe, University of Warsaw, 2012.

Balcerowicz, Bolesław. "Poland's Involvement in Euro-Atlantic Security." In Poland's Foreign Policy in the 21st Century, edited by Stanisław Bieleń, 132-146. Warsaw: Difin, 2011.

Barwiński, Marek. "Polish Interstate Relations with Ukraine, Belarus and Lithuania After 1990 in the Context of the Situation of National Minorities." European Spatial Research and Policy 20, no. 1 (2013): 5-26.

Bieleń, Stanisław, and Andrzej Skrzypek, eds. Geopolityka w stosunkach polsko-rosyjskich [Geopolitics in Polish-Russian relations]. Warszawa: Oficyna Wydawnicza ASPRA-JR, 2012 [In Polish].

Bieleń, Stanisław, and Andrzej Skrzypek, eds. Pamięć i polityka historyczna w stosunkach polsko-rosyjskich [Memory and historical policy in Polish-Russian relations]. Warszawa: Oficyna Wydawnicza ASPRA-JR 2017 [In Polish].

Bieleń, Stanisław, ed. Polityka wschodnia Polski między fatalizmem geopolitycznym a klątwa niemocy [Poland's Eastern Policy - Between Geopolitical Fatalism and the Curse of Impotence]. Warszawa: Oficyna Wydawnicza, 2019 [In Polish].

Boryniak Oleh, Marta Walak, and Ihor Hurak, eds. 20 rokiv polsko-ukraïns'kykh vidnosyn. Razom chy okremo? [20 years of Polish-Ukrainian relations. Together or Aapart?] Ivano-Frankivsk: Vydavnytstvo Prykarpatskoho natsionalnoho universytetu imeni Vasyla Stefanyka, 2013 [In Ukrainian].

Bunevich, Dmitri S. "The 'Strategic Thanatos' of Poland Trapped Midway between the Past and the Present." Russia in Global Affairs 4, no. 4 (2018): 72-94. https://doi.org/10.31278/1810-6374-2018-16-4-72-94.

Burant, Stephen R. “International Relations in a Regional Context: Poland and its Eastern Neighbours-Lithuania, Belarus, Ukraine." Europe Asia Studies 45, no. 3 (1993): 395-418. https://doi. org/10.1080/09668139308412098.

Burant, Stephen R. "Poland's Eastern Policy, 1990-95: The Limits of the Possible." Problems of PostCommunism, 43, no. 2 (1996): 48-55.

https://doi.org/10.1080/10758216.1996.11655669.

Chojan, Adrian. "From Strategy to Improvisation Poland's Eastern Policy in 2016-2018." Yearbook of the Institute of East-Central Europe 16, no. 4 (2018): 107-123.

Cienciala, Anna M., Natalia S. Lebedeva and Materski Wojciech. Katyn: A Crime Without Punishment. New Haven: Yale University Press, 2008.

Copeland, Dale C. "The Structural Challenge to Structural Realism: A Review Essay." In Constructivism and International Relations: Alexander Wendt and His Critics, edited by S. Guzzini and A. Leander, 1-20. Abingdon: Routledge, 2006.

Copsey, Nathaniel, and Karolina Pomorska. "Poland's Power and Influence in the European Union: The Case of its Eastern Policy." Comparative European Politics 8, no. 3 (2010): 306-324. https://doi.org/10.1057/ cep.2009.3.

Davies, Norman. God's Playground: A History of Poland: Volume 1: The Origins to 1795. Oxford: Oxford University Press, 2005a. 
Davies, Norman. God's Playground: A History of Poland: Volume 2: 1795 to the Present. Oxford: Oxford University Press, 2005b.

Drzewiecka, Jolanta A., and Marouf Hasian. "Discourses of the Wound and Desire for the Other: Remembrances of the Katyń Massacre and the Smoleńsk Crash." Review of Communication 18, no. 3 (2018): 231-248. https://doi.org/10.1080/15358593.201 8.1479883.

Dudek, Adrianna. “Użyteczność analitycznego eklektyzmu w badaniu stosunków Polski z Rosją" [The Utility of Analytical Eclecticism in the Study of Poland's Relations with Russia]. Stosunki Międzynarodowe International Relations 2, no. 52 (2016): 39-70.

Dyner, Anna M. "Poland's Policy Towards Belarus." In Yearbook of Polish Foreign Policy, edited by Sławomir Debski, 153-163. Warsaw: Polski Instytut Spraw Międzynarodowych. https://www.pism.pl/file/64670a5dc382-4916-a97c-9aceb861fa66.

Farrell, Henry, and Abraham L. Newman.

"Weaponized Interdependence: How Global Economic Networks Shape State Coercion." International Security 44, no. 1 (July 2019): 42-79. doi:10.1162/isec_a_00351.

Fedorowicz, Krzysztof. "National Identity and National Interest in Polish Eastern Policy, 1989-2004." Nationalities Papers 35, no. 3 (2007): 537-553. https://doi.org/10.1080/00905990701368761.

Fedorowicz, Krzysztof. Ukraina w polskiej polityce wschodniej w latach 1989-1999 [Ukraine in Polish Eastern Policy from 1989 to 1999]. Poznań: Adam Mickiewicz University in Poznań Press, 2004.

Feklyunina, Valentina. "Russia's foreign policy towards Poland: Seeking reconciliation? A social constructivist analysis." International Politics 49, no. 4 (2012): 434-448.

Fredheim, Rolf. "The Memory of Katyn in Polish Political Discourse: A Quantitative Study." Europe-Asia Studies 66, no. 7 (2014): 1165-1187.

https://doi.org/10.1080/09668136.2014.934135.

Goldman, Minton F. "Polish-Russian Relations and the 2004 Ukrainian Presidential Elections." East European Quarterly 45, no. 4 (2006): 409-428.

Gorska, Joanna A. Dealing with a Juggernaut: Analyzing Poland's Policy toward Russia, 1989-2009. Lanham: Lexington Books, 2010.

Hurak, Ihor. "Ukraine and Poland: Challenges to Strategic Partnership." Oriens Aliter. Journal for Culture and History of the Central and Eastern Europe 2, (2015): 20-39.

Singer, David J. "Reconstructing the Correlates of War Dataset on Material Capabilities of States, 18161985." International Interactions 14, (1987): 115-132. Jaroszewicz, Marta. Migration from Ukraine to Poland. Warsaw: Centre for Eastern Studies, 2018.

Khalitova, Liudmila et al. "He Who Pays the Piper, Calls the Tune? Examining Russia's and Poland's public Diplomacy Efforts to Shape the International Coverage of the Smolensk Crash." Public Relations Review 46, no. 2 (2020): 1-17. https://doi.org/10.1016/j. pubrev.2019.101858.

Korosteleva, Elena. Eastern Partnership: A New

Opportunity for the Neighbours. London: Routledge 2014.

Kuspys, Piotr. Współczesne stosunki polsko-ukraińskie. Polityka. Gospodarka. Wojsko. Sektor pozarzqdowy [Contemporary Polish-Ukrainian Relations. Politics. Economy. Military. Governmental Sector]. Kraków: Institute for Strategic Studies, 2009 [In Polish].

Kuźniar, Roman, and Andrzej Szeptycki. "The Role of the United States in the Foreign Policy of the Third Republic of Poland." In Bridges Across the Atlantic? Attitudes of Poles, Czechs and Slovaks Towards the United States, edited by Lena Kolarska-Bobińska, Jacek Kucharczyk, and Piotr M. Kaczyński, 115-151. Warsaw: Institute of Public Affairs, 2005.

Kuźniar, Roman. Poland's Foreign Policy after 1989.

Warsaw: Wydawnictwo Naukowe Scholar, 2009.

Lisiakiewicz, Rafał. "Poland's Conception of

European Security and Russia." Communist and Post-

Communist Studies 51, no. 2 (2018): 113-123.

https://doi.org/10.1016/j.postcomstud.2018.04.001.
Lisiakiewicz, Rafał. Polityka Rosji wobec Polski za prezydentury Władimira Putina (2000-2008) [Russia's Policy Towards Poland under President Vladimir Putin (2000-2008)]. Toruń: Wydawnictwo Adam Marszałek, 2011 [In Polish].

Makarychev, Andrey. "Normative and Civilisational Regionalisms: The EU, Russia and their Common Neighbourhoods." The International Spectator 53, no. 3 (2018): 1-19. https://doi.org/10.1080/03932729.2018.14 83630 .

McCgwire, Michael. "NATO Expansion: 'A Policy Error of historic importance."' Review of International Studies 24 (1998): 23-42. https://doi.org/10.1111/j.14682346.2008.00769.x

Mearsheimer, John J. The Tragedy of Great Power Politics. New York: W.W. Norton \& Company, 2003.

Menkiszak, Marek. “Difficult Neighbourhood: The Security Question in Polish Relations with Soviet Union and Russia." In Poland's Security Policy 1989-2000, edited by Roman Kuźniar, 125-170. Warsaw: Scholar, 2001.

Morgenthau, Hans. Politics Among Nations: The Struggle for Power and Peace. New York: Alfred A. Knopf, 1985.

Nagornyak, Tetyana, Iuliia Pachos, and Pavlo Bezuglyi. "Migration Processes in Modern UkrainianPolish Discourse." European Journal of Transformation Studies 8, no. 1 (2020): 33-48.

Nowak, Andrzej, ed. Rosja i Europa Wschodnia: "imperiologia" stosowana [Russia and Eastern Europe: "Applied Imperiology"]. Kraków: Wydawnictwo Arcana, 2006 [In Polish].

Nowak, Andrzej. History and Geopolitics: A Contest for Eastern Europe. Warszawa: Polski Instytut Spraw Międzynarodowych, 2008.

Pełczyńska-Nałęcz, Katarzyna. How Far Do the borders of the West Extend? Russian/Polish Strategic Conflicts in the Period 1990-2010. Warsaw: Centre for Eastern Studies, 2010.

Reeves, Christopher. "Reopening the Wounds of History? The Foreign Policy of the 'Fourth' Polish Republic." Journal of Communist Studies and Transition Politics 26, no. 4 (2010): 518-541. https://doi.org/10.1080 /13523279.2010.519189.

Rotfeld, Adam Daniel. "Government Information on the Polish Foreign Policy in 2005." In Yearbook of Polish Foreign Policy, edited by Sławomir Dębski, 9-15. Warsaw: Polski Instytut Spraw Międzynarodowych. Warsaw: Polski Instytut Spraw Międzynarodowych. https://www. pism.pl/file/64670a5d-c382-4916-a97c-9aceb861fa66.

Roth, Mathias. "Poland as a Policy Entrepreneur in European External Energy Policy: Towards Greater Energy Solidarity vis-à-vis Russia?" Geopolitics 16, no. 3 (2011): 600-625. https://doi.org/10.1080/14650045.201 1.520865 .

Sanford, George. Katyn and the Soviet Massacre of 1940: Truth, Justice and Memory. London: Routledge 2005.

Schweller, Randall L. "Bandwagoning for Profit: Bringing the Revisionist State Back In." International Security 19, no. 1 (1994): 72-107. https://doi. org/10.2307/2539149.

Snyder, Timothy. "Memory of Sovereignty and Sovereignty Over Memory: Poland, Lithuania and Ukraine, 1939-1999." In Memory and Power in Post-War Europe: Studies in the Presence of the Past, edited by JanWerner Müller, 39-58. Cambridge: Cambridge University Press, 2002. doi:10.1017/CBO9780511491580.002.

Snyder, Timothy. The Reconstruction of Nations. Poland, Ukraine, Lithuania, Belarus 1569-1999. New Haven: Yale University Press, 2003.

Staar, Richard Felix. Poland, 1944-1962: The Sovietization of a Captive People. Baton Rouge: Louisiana State University Press, 1962.

Stolarczyk, Mieczysław. Rosja w polityce zagranicznej Polski [Russia in Poland's Foreign Policy]. Katowice: Wydawnictwo Uniwersytetu Śląskiego, 2016 [In Polish].

Sydoruk, Tetiana, Pavlo Stepanets, and Iryna Tymeichuk. "Nord Stream 2 as a Threat to National Interests of Poland and Ukraine." Studia Politica. Romanian Political Science Review 19, no. 3-4 (2019): 467-490. 
Szeptycki, Andrzej. “Poland versus Russia: Competition in Ukraine." East European Politics and Societies: and Cultures, 2020. https://doi.org/10.1177\%2F0888325420950803.

Szeptycki, Andrzej. “Polish Knowledge Regarding the Transformation in Ukraine: A Case Study." In Three Revolutions: Mobilization and Change In Contemporary Ukraine. Volume I. Theoretical Aspects and Analyses on Religion, Memory and Identity, edited by Paweł Kowal, Georges Mink, and Iwona Reichardt, 359-392. Stuttgart: Ibidem Verlag, 2019b.

Szeptycki, Andrzej. "Polish-Ukrainian Relations: From the Success of the 'Orange Revolution' to Russia-first Policy." Polish Quarterly of International Affairs 19, no. 3 (2010): 5-25

Szeptycki, Andrzej. Contemporary Relations between Poland and Ukraine. "The Strategic Partnership" and the Limits Thereof. Berlin: Peter Lang, 2019a.

Walt, Stephen M., The Origins of Alliances. Ithaca: Cornell University, 1987.

Waltz, Kenneth N. Theory of International Politics. New York: McGraw-Hill, 1979.
Wohlforth, William C. "Realism and Foreign Policy." In Foreign Policy. Theories, Actors, Cases, edited by Steve Smith, Amelia Hadfield, and Tim Dunne, 35-53. Oxford: Oxford University Press, 2016.

Wolczuk, Kataryna, and Roman Wolczuk. Poland and Ukraine: A Strategic Partnership in a Changing Europe? Maintaining a Strategic Partnership Through a New Iron Curtain? London: Chatham House, 2003.

Wyciszkiewicz, Ernest. "Poland's Policy Regarding Countries of South Caucasus and Central Asia." In Yearbook of Polish Foreign Policy, 234-249. https:// www.ceeol.com/search/article-detail?id=54847.

Zieliński, Miłosz J. “Cross-Border Co-Operation between the Kaliningrad Oblast and Poland in the Context of Polish-Russian Relations in 2004-2011." Lithuanian Foreign Policy Review 28 (2012): 11-42.

Żukowski, Arkadiusz, and Marcin Chełminiak. "PolishRussian Cross-Border Cooperation from the Perspective of Polish Foreign Policy. General View." Regional Formation and Development Studies 17, no. 3 (2015): 181-188.

\section{Author}

Andrzej Szeptycki,

Professor, Department of Strategic Studies and International Security,

Faculty of Political Science and International Studies,

University of Warsaw. Warszawa, Poland,

ul. Żurawia 4, room 406, 40700-503.

e-mail: andrzej.szeptycki@uw.edu.pl

\section{Additional information}

Received: February 15, 2021. Accepted: April 15, 2021.

\section{Disclosure statement}

No potential conflict of interest was reported by the author.

\section{For citation}

Szeptycki, Andrzej. "Polish Take on Realism: Poland's Policy Towards the Former Soviet Countries, 1991-2021." Journal of International Analytics 12, no. 1 (2021): 132-145.

https://doi.org/10.46272/2587-8476-2021-12-1-132-145 


\title{
Реализм по-польски:
}

\section{политика Польши в отношении бывших советских республик, 1991-2021 гг.}

\begin{abstract}
АННОТАЦИЯ
В статье анализируется восточный вектор политики Польши в отношении постсоветского пространства через теорию реализма международных отношений. В первой части статьи рассматриваются ключевые положения реалисткой теории международных отношений, во второй - существующая литература о внешней политике Польши. В третьей части автор рассматривает детерминанты политики Польши в отношении постсоветских государств (история ее отношений с регионом, идеологические основы ее политики, существующие вопросы безопасности и т.д.). В последней части автор задается вопросом об эволюции политики Польши до настоящего времени. Российская Федерация воспринимается Польшей как значительная угроза. В этом контексте с начала 1990-х гг. Польша искала решения для укрепления своей безопасности. Она стремилась присоединиться к Североатлантическому

альянсу и установить тесное партнерство с Соединенными Штатами (в реалистской парадигме - примыкание, bandwagoning). Эта стратегия принесла существенный эффект: в 1999 г. Польша вступила в НАТО и с тех пор на ее территории размещены войска союзников. Польша также стремилась развивать сотрудничество с Украиной (в большей степени, чем с другими постсоветскими соседями) и приблизить их к евроатлантическим структурам. Эта политика была направлена, в частности, на ослабление влияния России в регионе (в реалистской парадигме - балансирование, balancing). Однако результаты этой стратегии оказались неоднозначными. Несмотря на то что Украина отвергла продвигаемые Россией проекты реинтеграции в постсоветское пространство, процесс реформ в этой стране идет медленно. Что касается других постсоветских государств, то Польша в основном оказалась неспособной повлиять на желаемые политические изменения в этих странах.
\end{abstract}

\section{КЛЮЧЕВЫЕ СЛОВА}

Польша, внешняя политика, Россия, Восточная Европа, реализм

\section{Сведения об авторе}

Анджей Шептицкий,

профессор кафедры стратегических исследований и международной безопасности,

Факультет политических наук и международных исследований,

Варшавский университет. Варшава, Польша, ul. Żurawia 4, комната 406, 40700-503.

e-mail: andrzej.szeptycki@uw.edu.pl

Дополнительная информация

Поступила в редакцию: 15 февраля 2021. Принята к публикации: 15 апреля 2021.

\section{Конфликт интересов}

Автор заявляет об отсутствии конфликта интересов.

\section{Цитирование}

Шептицкий, А. Реализм по-польски: политика Польши в отношении бывших

советских республик, 1991-2021 гг. // Международная аналитика. - 2021. - Том 12 (1). - С. 132-145. https://doi.org/10.46272/2587-8476-2021-12-1-132-145 